\title{
Open-Book Management and Organizational Success of Deposit Money Banks in South-South, Nigeria
}

\author{
${ }^{1}$ Vito Baridula, Ph.D, ${ }^{2}$ Joy A. Mekuri-Ndimele, Ph.D \\ ${ }^{1}$ Depart of Management, Faculty of Business Studies, Ignatus Ajuru University of Education, Port Harcourt. \\ ${ }^{2}$ Department of Office and Information Management, Faculty of Business Studies, Ignatus Ajuru University \\ of Education, Port Harcourt
}

\begin{abstract}
Organizational success is of the main drivers in achieving organizational goal and objectives as indicated in literature. Based on this evidenced the study focused the relationship between open book management and organizational success of deposit money banks in Nigeria. The study adopted quasi-experimental research design and examined the population of 200 employees with a sample size of 133 respondents in four deposit money banks in Nigeria. Questionnaire was the measure instrument for data collection and the collected data were analyzed using Spearman's' Rank Order Correlation Coefficient statistic. The result shows a significant relationship between the dimensions of open book management and organizational success measures of deposit money banks in Nigeria. Therefore, the study concluded that open book management affect organizational success and recommended that management should periodically make employees to know about the financial statues of the organization and to develop employees' recognition programs and provide pay-performance programs that will stimulate employees' performance toward achievement of organizational success.
\end{abstract}

Keywords: Open-Book Management, Organisational Success, Pay-For-Performance, Financial Growth, Employee Recognition, Survival

\section{Introduction}

Financial institutions are organization that deals with money and their degree of realizing their goal indicates their continuing in business operation. Financial institutions have made remarkable impact on the nation's economy as well as providing fund to individuals in form of credit to help individuals in business operation. Based on these roles, their major aim is to achieve organizational success and remain in business operations. Organizational success is achieved when a firm meets its target and survive is the midst at challenging business entities. Their success lies in financial growth and survival thereby demanding that much attention should be given to success variables. However, they also need to examine other variables that facilitate financial growth and survival.

There are several variables that are responsible for organizational success such as; employee development (Rheem, 1996) employees reward system or compensation (Abbott, 1993); employees motivation (Lencioni, 2009) and others. However, it seems that in the financial institution, much attention have not been extended to open book management which is a motivational approach in which an organization financial statements (the 'book) is shared with all employees to know the extent to which the organization is progressing so that they can take active share through their performance (DeNisi \& Griffin, 2005). Open book management includes setting employee recognition programs and pay-performance programs which will make employees to think in the same direction with the owner of organization as they see the impact of their decision and performance on financial results.

Although, scholars have developed interest in examining how open book management helps employees as well as management to improve performance, however, very little regard have been extended by researchers in studying the relationship between open book management and organizational success of financial 
institutions in south-south, Nigeria. As a critical concept this led the present study that examined the relationship between open book management and organizational success in deposit money banks in southsouth zone in Nigeria to bridge this gap in literature.

\section{Statement of the Problem}

Open book management can bring about organizational success. This is due to the fact that firms that designed employees' recognition programs and set up pay-performance programs do better than firms that does not. Employees' recognition programs and set up of pay-performance programs are critical factors for financial growth and ensures chance for survival. These are major challenges faced by deposit money banks in south-south, Nigeria. These problems stemmed from low employee motivation resulted in decreased employee performance. Some deposit money banks failed to perform to their expectations in the midst of their competitions. Hence chance for survival becomes minimal and to continue in business operations becomes a great challenge. Hence, many employees tend to defect to other sector for jobs which has caused high rate of employee defection which eventually affect the performance of the financial institutions.

The degree of motivating employees through recognition programs and pay-performance would have helped to improve the performance of the organization to meet its target. Additionally, set up pay-performance programs (Maher \& Hudson, 2007) would have assisted employees to think in the same direction with the business owners to meet the set target. However, most of these financial institutions do not practice open book management in their business operations which has caused poor performance and failures to achieve set goal which strangled the survival of deposit money banks in South-south, Nigeria. Seeing these as critical problems to the survival of financial institutions in south-south zone in Nigeria 'has demanded an investigation to examine the relationship between open book management and organizational success in deposit money banks in south-south, Nigeria. Furthermore, to solve these problems, two theories were fund useful and were adopted in addressing these issues and providing recommendations that will help deposit money banks in south-south zone to attain organizational success.

\section{Aim and Objectives of the Study}

The aim of the study is to examine the relationship between open book management and organizational success in deposit money banks in south-south, Nigeria. The specific objectives of the study are to;

i. Examine the relationship between employees' recognition programs and financial growth in deposit money banks in south-south, Nigeria.

ii. Ascertain the relationship between employees' recognition programs and survival of deposit money banks in south-south, Nigeria.

iii. Investigate the relationship between pay-performance program and financial growth in deposit money banks in south-south, Nigeria.

iv. Evaluate the relationship between pay-performance programs and survival of deposit money banks in south-south, Nigeria.

\section{Research Questions}

Based on the objective of the study the following research question were developed and analyzed in the study.

i. What is the relationship between employees' recognition programs and financial growth in deposit money banks in south-south zone in Nigeria?

ii. How does employees' recognition programs relate to survival of deposit money banks in south south zone in Nigeria?

iii. What is the relationship between pay-performance programs and financial growth in deposit money banks in south-south zone in Nigeria?

iv. How does pay-performance programs relate to survival of deposit money banks in south-south zone in Nigeria?

\section{Hypotheses}

The following null statements of hypotheses were tested to generate answers to the research questions: 
Ho1: There is no significant relationship between employee involvement and financial growth ofDeposit Money Banks in South-South, Nigeria.

Ho2: Employee involvement does not have any significant relationship with survival of deposit money banks in South-South, Nigeria.

Ho3: There is no significant relationship between pay-performance programs and financial growth in deposit money banks in South-South, Nigeria

Ho4: Pay-performance programs do not have any significant relationship with survival of Deposit

Money Banks in South-South, Nigeria.

\section{Significance of the Study}

This study will assist the financial institutions in Nigeria in their policy making on how to improve employees' performance in the financial institutions. The extent to which the organization will achieve the set goal will depend on the adoption of open book management concept in their business operation; hence, employees will value the involvement in financial status in order to improve their performance level. Scholars will find this study useful in future research studies since much investigation have not been conducted on open book management and organizational success in Nigerian financial institutions'

\section{Literature Review \\ Theoretical Framework}

This study adopted the reinforcement theory. The reinforcement theory states that behavior is a function of its consequences. Those consequences that immediately follow a behavior and increase the probability that the behavior will be repeated are called reinforcers. Reinforcement theory ignores factors such as goals, expectations, and needs. Instead, it focuses solely on what happens to a person when they do something that is annual (Maher \& Hudson, 2007). The company's intent: is to keep the workforce motivated to meet goals by rewarding them when they did, thus reinforcing the behaviors also widely believed to explain motivation. People will most likely engage in desired behaviors if they are rewarded for doing so. These rewards are most effective if they immediately follow a desired behavior; and behavior that is not rewarded, or is punished, is less likely to be repeated.

Using reinforcement theory, managers can influence employees' behavior by using positive reinforces for actions that help the organization achieve its goals. Managers should ignore, not punish, undesirable behavior, Although punishment eliminates undesired behavior faster than non reinforcement does, its effect is often temporary and may have pleasant side effects including dysfunctional behavior such as workplace conflicts, 'absenteeism, and turnover.

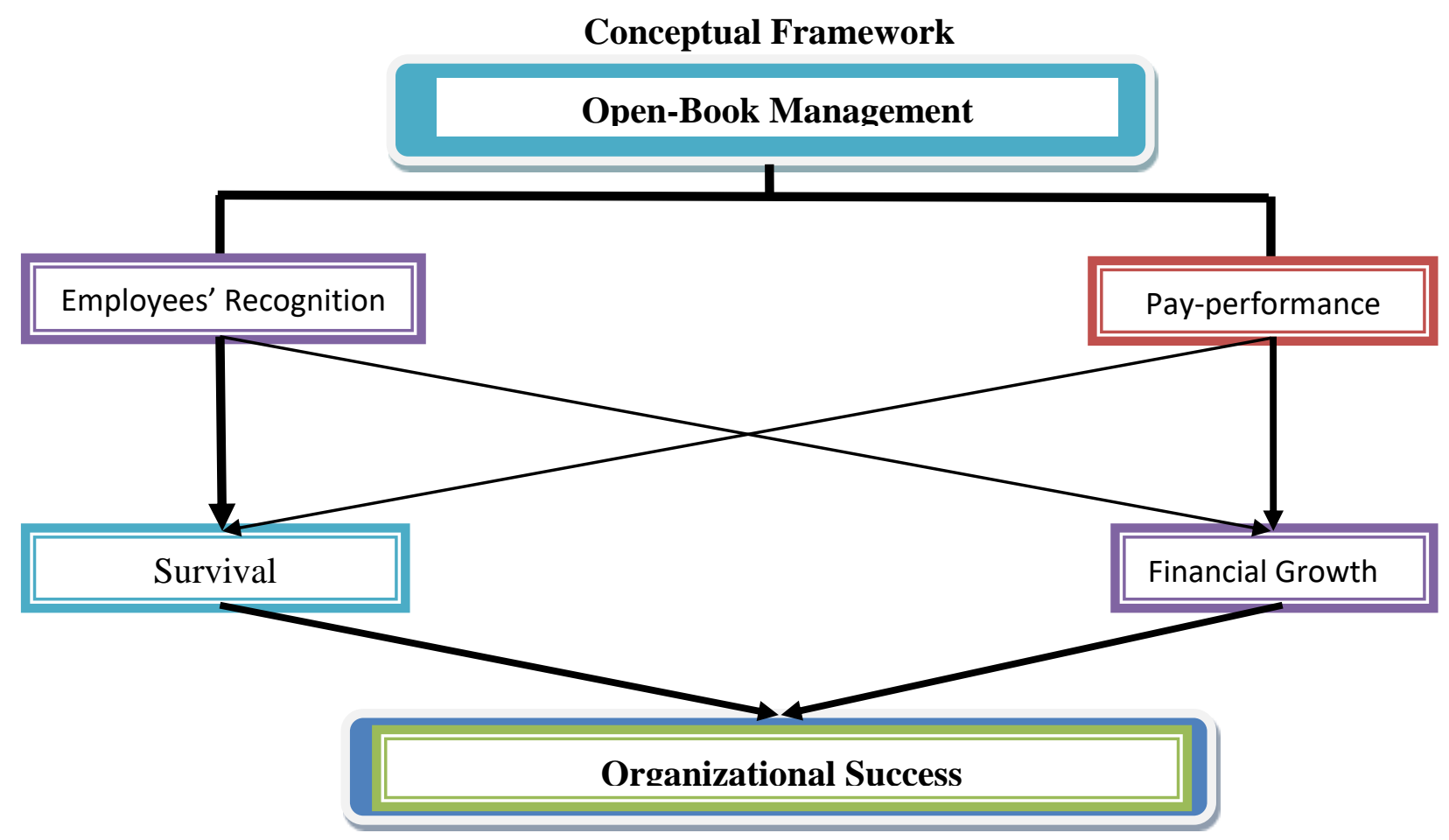




\section{Open Book Management}

Open book management is a motivational approach in which organizational financial statements (the books) are shared with all employees (Robbins \& Coulter, 2013). Employees are the main drivers of the objectives of the organization. This means that without employees financial institutions cannot achieve that set target. Their performance determine the success of the organization in this case, they need to be involved in critical decisions by management as means to motivate them to improve their performance toward goal attainment. This is the essence of open book management. The financial statements called the books' are made available to employees so that they are aware of where the firm is driving to, and the target they seek to achieve.

As Robbins and Coulter (2013) noted, when the information or the books are available to employees they are motivated to make better decision concerning their performance and gain move understanding of the implications of what they do, the way to do them and the extent to which what they do affects the outcomes of their performance and that of the firm. It requires that employees should constantly receive updates on the financial condition of the institution sxo that employees can expand more effort and commitment in finding ways that will minimize expenses and costs of operations for the institution to achieve its target. It is true that most of the employees may not possess the knowledge of financial statement but the extent to which management educate them on it will make them to understand it more better than they are on their own. In this case management need to regularly share the figure with them so that they can begin to understand efforts, and then level of performance with respect to what is set to achieve.

As Robbins and Coulter (2013) noted, when the information or the books are available to employees they are motivated to make better decision concerning their performance and gain move understanding of the implications of what they do, the way to do them and the extent to which what they do affects the outcomes of their performance and that of the firm. It requires that employees should constantly receive updates on the financial condition of the institution sxo that employees can expand more effort and commitment in finding ways that will minimize expenses and costs of operations for the institution to achieve its target. It is true that most of the employees ay not possess the knowledge of financial statement but the extent to which management educate them on it will make them to understand it more better than they are on their own. In this case management need to regularly share the figure with them so that they can begin to understand efforts, and then level of performance with respect to what set to achieve.

For instance, Lencioni (2009) noted that at Parrish Medical Center in Titusville, Florida, CEO George Mikitarian pas struggling with the prospect of massive layoffs, facilities closing, and profits decline. Since many employees don't have knowledge or background to understand the financials, they have to be taught how to ad and understand the organization's financial statements. Once employees have this knowledge, however, managers need to regularly share the numbers with them. By sharing information, employees begin to see the link between their efforts, level of performance.

\section{Employee Recognition Programs}

Employee recognition programs are one means of prating open book management. Employees recognition programs consist of personal attention and expressing interest, approval, and appreciation for a job well done. An example of employees' recognition programs in action was observed by Robbins and Coulter (2013) when an organization called 'Kelly services' introduced a new version of its point-based incentive system to better advance retention and productivity among its employees.

As Robbins and Coulter (2013) noted, the program, called 'Kelly Kudos' presented to the employees more choices of awards and provided them with the opportunity to accumulate points over a longer time period. As a result those who participated (the employees) produced three time revenue the more than employees not accumulating points. Furthermore, A recent survey of organizations found that 84 percent had some type of program to recognize worker achievements (Dunham, 2002).

Consistent with reinforcement theory, rewarding a behavior with recognition immediately following that behavior is likely to encourage its repetition. Additionally, recognition can take many forms. Management 
can personally congratulate an employee in private for a good job. They can send a handwritten note or email message acknowledging something positive that the employee has done. For employees with a strong need for social acceptance, management can publicly recognize accomplishments. To enhance group cohesiveness and motivation, management can celebrate team successes. For instance, they can do something as simple as throw a pizza party to celebrate a team's accomplishments. According to Flandez (2009), during the economic recession, managers got quite creative in how they showed employees they were appreciated. As an example, employees at one company got to take home fresh vegetables from the company vegetal garden. In others, managers treated employees who really put forth efforts on a project to a special meal or movie tickets. Also, managers can show employees that no matter what his or her role may be that their contributions matter to the success of the organization. Some of these things may seem simple but they can go a long way in showing employees that they are valued.

\section{Pay-For-performance}

According to White (2006) pay-for-performance programs are variable compensation plans that pay employees on the basis of some performance measure. Piece-rate pay plan, wage incentive plans, profitsharing, and lump-sum bonuses are examples. What differentiates these forms of pay from more traditional compensation plans is that instead of paying person for time on the job, pay is adjusted to reflect some performance measure. This performance measures include such things as individual productivity, team or work group productivity, departmental productivity, or the overall organization's profit performance.

Pay-for-performance is probably most compatible with expectancy theory (White, 2006). Individuals should perceive a strong relationship between their performance and the rewards they receive for motivation to be maximized. If rewards are allocated only on nonperformance factors such as seniority, job title, or acrossthe-board pay raises - then employees are likely to reduce their efforts. From a motivation perspective, making some or all an employee's pay conditional on some performance measure focuses his or her attention and effort toward that measure, then reinforces the continuation of the effort with a reward. If the employee's team's or organization's performance declines, so does the reward. Thus, there's an incentive to keep efforts and motivation strong.

Pay-for-performance programs are popular. For example, some 80 percent of large U.S. companies have some form of variable pay plan (White (2006). These types of pay plans have also been tried in other countries such as Canada and Japan. About 30 percent of Canadian companies and 22 percent of Japanese companies have company-wide pay-for-performance plans (Beauchesne, 2002. One may ask whether payfor-performance programs actually work. However, for the most part, studies seem to indicate that pay-forperformance programs do. For instance, the study by Rheem (1996) found that companies that used pay-forperformance programs performed better financially than those that did not.

Another study by Banker et al. (1996) showed that pay-for-performance programs with outcome-based incentives had a positive impact on sales, customer satisfaction, and profits. Hence, if an organization uses work teams, managers should consider group-based performance incentives that will reinforce team effort and commitment. But whether these programs are individual based or team based, managers need to ensure that they are specific about the relationship between an individual's pay and his or her expected level of appropriate performance. Reason (2003) posits that employees must clearly understand exactly how their performance and the organization translate into success of entire organization.

\section{Organizational success}

Organizational success is a central issue in organizational studies, and growth is often believed to be an adequate indicator of organizational success. As Whetten (1980) remarked, in general, organizational growth is an implicit assumption in research studies because it is generally assumed that "growth is synonymous with effectiveness", that "bigger is better" and that "there is a positive correlation between size and age. Other definitions of success emphasize the time dimension. For example, according to Miller and Friesen (1978), success is related to "the degree to which the firms are able to achieve their objectives subject to the constraints of long run viability. Though much less popular than organizational success (Whetten, 1987), organizational failure has also been referred to in the literature in different ways. These 
include: organizational mortality, organizational death, organizational exit, bankruptcy, decline, retrenchment and downsizing (Mellahi \& Wilkinson, 2004).

\section{Survival}

Survival is the greatest goal of many business organizations today. In this time, so many companies are striving to remain in business operations, due to competitive nature of business and this becomes the main concern of many organizations especially the money deposit banks in Nigeria. Survival has been conceived as the extent of staying in business operations for a long time and attained to changes and adapt to turbulent times. Before an organization could survive to thay aspect it must make sure that all the organizational resources and configured towards the determined objectives of the organization. Secondly, the organization must develop the need capacity with flexibility to maximize the output of the organization. One iof the best ways to attain survival is to adopt open book management which will make employees to be recognized and work with the organization because they understand the profitability of the organization and the goal of the business. With all of these, it is expected that the level of organizational performance towards survival will improve through the adoption of open book management.

\section{Financial Growth}

Profitability or profit maximization is a financial growth metric. Profit is defined as the money a firm makes after paying its employees and covering other expenses (Nickels et al., 2011). Profit is one of the most important aspects of any business enterprise. As a result, profitability denotes a profitable state or the extent to which a business is profitable. Profitability is the primary objective of all company for profit (Amah, 2006). Without profitability, the company will not be able to survive in the long run. A very profitable firm, on the other hand, has the potential to provide its owners with a large return on their investment. According to Sulait (2010), Profitability is a performance metric that is identified and used by business owners, managers, investors, and others who are interested in knowing the company's earnings, which are usually a sales margin. As a result, the profit generator may be used to measure a company's economic progress. Any firm that creates large positive cash flows or earnings that expand at a quicker rate than the general economy is considered a growth company.

\section{Method}

The study adopted quasi-experimental research designed since it is a cross sectional survey study. One of the reasons why the study adopts a quasi-experimental design is because, the variables are outside the control of the researcher, and research is also a descriptive research in nature. The target population of the study consisted of all respondents in telecommunications companies in Port Harcourt. However, the accessible population was 200 respondents consisted of managers and supervisors in four (4) money deposit banks in Nigeria. For the accessible population, the study focused four deposit money banks operating n Rivers State since most of the banks have their Branches in Rivers State. The 200 respondents were determined using convenient sampling as deemed fit for study in terms of generalization of findings. The financial institutions are; Fidelity bank, UBA bank, Eco-bank and Sterling bank. To determine the sample size, the study, Taro Yamene's formula was adopted. Hence, 133 copies of questionnaire will be distributed to the telecommunication firms in Port Harcourt based on their individual sample size. Printed copies of questionnaire and were used in data collection for the study. The reason for using questionnaire is because it enables the respondents to have enough time and opportunity to ponder over the questions before filling it. Basically the primary data were collected from the respondents directly on the sport. The secondary information was collected from journals articles, text books and other publication related to the subject under review. Questionnaire was designed used for data collection. This study is concerned with two variables; these are the independent and dependent variables. The independent variable of this study is relational capital, while the dependent variable is organizational survival.

The dimensions of open book management were adopted which includes: employees' recognition programs and pay-performance programs. Five items each were used to measure this variable on a modified Likert 4 points scale, ranging from strongly agree to strongly disagree. Where strongly agree scored $=4$ points, agree 
$=3$ points, disagree $=2$ points, and strongly disagree $=1$ point. The measures of organizational success include employee involvement and goal attainment. Five items each were used to measure these variables on a Likert 4 points scale, ranging from strongly agrees to strongly disagree. Where strongly agree scored $=4$ points, agree $=5$ pcints, disagree $=2$ points and strongly disagree $=1$ point

Concerning validity of the instrument, to prove that the instrument is reliable, the study engaged in calculation of items to achieve a Cronbah's Alpha of 0.7 which is considered appropriate by Nunally (1978). This was performed through SPSS version (23.0). The hypotheses were tested using Spearman's Rank order Correlation coefficient (Rho). The technique is a measure of association between the variables. The study involved two-tailed test and data collected were at the ordinal level. The decision on test of the hypotheses stated was based on the value correlation expressed in table below.

\section{Results and Discussion}

Table 1 showed that $133(100 \%)$ copies of the questionnaires were distributed to managers, supervisors and employees selected from four (4) deposit money banks firms in south-south, Nigeria. Out of the 133(100\%) copies of questionnaire administered, only 122(91.7\%) were retrieved, while 11 copies which is $(8.3 \%)$ were rejected. Thus, the $122(91.7 \%)$ formed the basis of the analysis.

\section{Demographic Data Analysis}

Tables 4cover the demographic data collected of Section A of the administered questionnaire and presented as shown below:

Table 2 Gender

\begin{tabular}{|l|l|l|}
\hline Response & No of Respondents & Respondents' (\%) \\
\hline Male & 78 & 63.9 \\
\hline Female & 44 & 36.1 \\
\hline Total & $\mathbf{1 2 2}$ & $\mathbf{1 0 0 \%}$ \\
\hline
\end{tabular}

Source: Field data, (2021).

Table 2 shows that $78(61 \%)$ of the respondents were male while the female were 44 representing $36.1 \%$ of the total respondents. It shows that the majority of respondents were male since they had higher respondents' distribution than the female.

\section{Table 3 Marital Status}

\begin{tabular}{|l|l|l|}
\hline Response Variables & No of & Respondents' \% \\
\hline Single & 65 & 53.3 \\
\hline Married & 57 & 46.7 \\
\hline Total & $\mathbf{1 2 2}$ & $\mathbf{1 0 0}$ \\
\hline
\end{tabular}

Source: Field data, (2021).

Table 3 indicates that 65(53.3) representing single respondents. While the married respondents 57 representing $46.7 \%$ of the total respondents. The single respondents are the highest response rate.

Table 4 Educational Qualification

\begin{tabular}{|l|l|l|}
\hline Levels of Qualifications & Response rate & Percentage \\
\hline Diploma & 34 & 27.9 \\
\hline First Degree & 48 & 39.3 \\
\hline Master's Degree & 32 & 26.2 \\
\hline Ph.D. Degree & 8 & 6.6 \\
\hline Total & $\mathbf{1 2 2}$ & $\mathbf{1 0 0}$ \\
\hline
\end{tabular}

Source; Field data, (2021).

Table 4 indicates that the majority of the respondents are holders of first degree which represents $48 \%$ of the total respondents, followed by respondents with diploma educational qualification and 32 respondents representing $26.2 \%$ are master's degree holders, while only $8(6.6 \%)$ are $\mathrm{PhD}$ degree holders. 
Table 5 Positions of Respondents.

\begin{tabular}{|l|l|l|}
\hline Positions & Frequency & Valid Percent \\
\hline Top Management & 38 & 31.1 \\
\hline Managers & 44 & 36.1 \\
\hline Supervisor & 40 & 32.8 \\
\hline Total & 122 & 100 \\
\hline
\end{tabular}

Source: Fieldwork, (2021).

Table 5 above shows that the top management respondents were 38 representing $31.1 \%$; 44 respondents were Managers representing 36.1\%, while 40 respondents were supervisors were representing 32.8\%. The analysis shows that majority of the respondents were Managers.

\section{Analysis of Research Questions}

At this juncture, the study begins to analyze the research questions using descriptive statistics (univaririate and percentage rate) to ascertain the respond categories that is mostly responded to and the decision is based on majority that responded successfully.

\section{Descriptive or Univariate}

Analysis of the items on the questionnaire based on mean and standard deviation. Since it is a Likert's five point scale adopted, the mean as benchmark becomes: $2.5(1+2+3+4 / 4)$ This shows that responses to variable that meet the 2.5 mean mark were accepted for the study.

\section{Table 6 Scores of the Study Variables}

Variable Statistics

\begin{tabular}{|l|l|l|l|}
\hline Variables & Mean & $\begin{array}{l}\text { Std. } \\
\text { Deviation }\end{array}$ & N \\
\hline Employees' recognition programs & 2.7020 & 1.18384 & 122 \\
Pay-performance programs & 3.1560 & 1.20542 & 122 \\
Financial growth & 2.6040 & 1.34845 & 122 \\
Survival & 2.8200 & 1.12258 & 122 \\
\hline
\end{tabular}

Source: SPSS Data Output. (2021).

From table 6 the mean score of the items are above 2.5 benchmark mean. Hence, it is accepted that the response rates for the four variables are positive.

\section{Test of Hypothesis One}

$\mathbf{H}_{\mathbf{0 1}}$ : There is no significant relationship between employees' recognition programs and goal attainment in deposit money banks in south-south region in Nigeria.

Table 7 Correlation between Employees' Recognition Programs and Goal Attainment

\begin{tabular}{|c|c|c|c|c|}
\hline \multicolumn{5}{|c|}{ Correlations } \\
\hline & & & $\begin{array}{l}\text { Employees' } \\
\text { recognition } \\
\text { programs }\end{array}$ & $\begin{array}{l}\text { Financial } \\
\text { growth }\end{array}$ \\
\hline \multirow[t]{4}{*}{$\begin{array}{l}\text { Spearman's } \\
\text { rho }\end{array}$} & \multirow{3}{*}{$\begin{array}{l}\text { Employees' recognition } \\
\text { programs }\end{array}$} & $\begin{array}{l}\text { Correlation } \\
\text { Coefficient }\end{array}$ & 1.000 & .663 \\
\hline & & Sig. (2-tailed) & . & .000 \\
\hline & & $\mathrm{N}$ & 145 & 145 \\
\hline & & Correlation & $.663^{\prime \prime}$ & 1.000 \\
\hline
\end{tabular}




\begin{tabular}{|l|l|l|r|r|}
\hline \multirow{2}{*}{} & Financial growth & Coefficient & \\
\cline { 3 - 4 } & & Sig. (2-tailed) & .000 & \\
\cline { 2 - 4 } & & $\mathrm{N}$ & 122 & 122 \\
\hline${ }^{* *}$. Correlation is significant at the 0.05 level (2-tailed). & \\
\hline
\end{tabular}

The hypothesis stated sought to determine the extent to which employees' recognition programs relate to goal attainment. The result revealed that employee involvement has a strong positive relationship (.663) with financial growth when the $\mathrm{P}$-value $=.000<0.05$. Therefore, $\mathrm{Ho}_{1}$ is rejected and concluded that there is a significant relationship between employees' recognition programs and financial growth in deposit money banks in south-south region in Nigeria.

\section{Test of Hypotheses Two}

$\mathbf{H}_{\mathbf{0 2}}$ : There is no significant relationship between Employees' Recognition Programs and Survival in deposit money banks in south-south region in Nigeria.

Table 8 Correlation between employees' recognition programs and survival

\begin{tabular}{|c|c|c|c|c|}
\hline \multicolumn{5}{|c|}{ Correlations } \\
\hline & & & $\begin{array}{l}\text { Employees' } \\
\text { recognition } \\
\text { programs }\end{array}$ & Survival \\
\hline \multirow[t]{6}{*}{$\begin{array}{l}\text { Spearman's } \\
\text { rho }\end{array}$} & \multirow{3}{*}{$\begin{array}{l}\text { Employees' recognition } \\
\text { programs }\end{array}$} & $\begin{array}{l}\text { Correlation } \\
\text { Coefficient }\end{array}$ & 1.000 & $.747^{\prime \prime}$ \\
\hline & & Sig. (2-tailed) & & .000 \\
\hline & & $\mathrm{N}$ & 122 & 122 \\
\hline & \multirow[t]{3}{*}{ Survival } & $\begin{array}{l}\text { Correlation } \\
\text { Coefficient }\end{array}$ & $.747^{\circ}$ & 1.000 \\
\hline & & Sig. (2-tailed) & .000 & \\
\hline & & $\mathrm{N}$ & 122 & 122 \\
\hline
\end{tabular}

The second hypotheses were stated to examine the extent to which employees' recognition programs relates to survival. The result revealed that employee involvement has a significant and strong positive relationship of .747 with growth, when the $\mathrm{P}$-value $=.000<0.05$ ). Therefore, the study rejects $\mathrm{H}_{2}$ and accepted that there is a significant relationship between employees' recognition programs and survival in deposit money banks in south-south region in Nigeria.

$\mathbf{H}_{\mathbf{0 3}}$ : There is no significant relationship between pay-performance programs and survival in deposit money banks in south-south region in Nigeria.

\section{Test of Hypotheses Three}

Table 9 Correlation between Pay-Performance Programs and Financial growth

\begin{tabular}{|c|c|c|c|c|}
\hline \multicolumn{5}{|c|}{ Correlations } \\
\hline & & & $\begin{array}{l}\text { Pay- } \\
\text { performance } \\
\text { Programs }\end{array}$ & $\begin{array}{l}\text { Financial } \\
\text { growth }\end{array}$ \\
\hline \multirow[t]{6}{*}{$\begin{array}{l}\text { Spearman's } \\
\text { rho }\end{array}$} & \multirow{3}{*}{$\begin{array}{l}\text { Pay-performance } \\
\text { Programs }\end{array}$} & $\begin{array}{l}\text { Correlation } \\
\text { Coefficient }\end{array}$ & 1.000 & $.650^{*}$ \\
\hline & & Sig. (2-tailed) & · & .000 \\
\hline & & $\mathrm{N}$ & 122 & 122 \\
\hline & \multirow[t]{3}{*}{ Financial growth } & $\begin{array}{l}\text { Correlation } \\
\text { Coefficient }\end{array}$ & $.650^{\circ}$ & 1.000 \\
\hline & & Sig. (2-tailed) & .000 & . \\
\hline & & $\mathrm{N}$ & 122 & 122 \\
\hline
\end{tabular}


The third hypotheses stated focused on the extent to which pay-performance programs relate to goal attainment. The result revealed that pay-performance programs has a strong positive and significant relationship of 0.650 with goal attainment, when the $\mathrm{P}$ - value $=.000<0.05$ ). Therefore, the study rejects $\mathrm{HO}_{3}$ and accepted that there is a significant relationship between pay-performance programs and financial growth in deposit money banks in south-south region in Nigeria.

\section{Test of hypotheses Four}

Ho⿱ : There is no significant relationship between pay-performance programs and survival in telecommunication companies in Port Harcourt.

Table 10 Correlation between Pay-Performance Programs and Survival

\begin{tabular}{|c|c|c|c|c|}
\hline \multicolumn{5}{|c|}{ Correlations } \\
\hline & & & $\begin{array}{l}\text { Employee's } \\
\text { Recognition } \\
\text { Program }\end{array}$ & Survival \\
\hline \multirow[t]{6}{*}{$\begin{array}{l}\text { Spearman's } \\
\text { rho }\end{array}$} & \multirow{3}{*}{$\begin{array}{l}\text { Pay-performance } \\
\text { Program }\end{array}$} & $\begin{array}{l}\text { Correlation } \\
\text { Coefficient }\end{array}$ & 1.000 & .530 \\
\hline & & Sig. (2-tailed) & . & .000 \\
\hline & & $\mathrm{N}$ & 122 & 122 \\
\hline & \multirow[t]{3}{*}{ Survival } & $\begin{array}{l}\text { Correlation } \\
\text { Coefficient }\end{array}$ & .530 & 1.000 \\
\hline & & Sig. (2-tailed) & .000 & \\
\hline & & $\mathrm{N}$ & 122 & 122 \\
\hline
\end{tabular}

The fourth hypotheses stated examined the extent to which business pay-performance programs relates to survival. The result of the analysis shows that pay-performance programs has a significant and positive relationship of 0.530 with survival, when the P-value $=.000<0.05$ ) Therefore, we reject $\mathrm{H}_{4}$ and accepted that there is a significant relationship between pay-performance programs and survival in in deposit money banks in south-south region in Nigeria.

\section{Conclusion}

From the findings, it is clear that open book management play an important role in the behavior and performance of employees towards the attainment of financial growth. Therefore, the study concludes that open book management affect organizational success deposit money banks in Nigeria. This is due to the fact that management failed to let employees know what the organization is achieving in terms of profit and other advancements. This created unfavorable conditions for employees which adversely affected their level of performance towards organizational success.

\section{Recommendations}

Based the findings and conclusion, the study recommended that management should periodically make employees to know about the financial statues of the organization and to develop employees' recognition programs and provide pay-performance programs that will stimulate employees performance toward achievement of organizational success.;

\section{Contributions to Knowledge}

This study contributes to literature on the concept of open book management and organizational success in deposit money banks in Nigeria since such study is limited in this sector. This study also makes an effective review of past studies and developed a framework which was used in examining and explaining why open book management is essential for attainment of organizational success.

\section{Areas for Future Research}

The extent to which open book management is studied in literature is very minimal and the how organizations in Nigeria practice open book management are at low level. Hence, further research is needed to examine how open book management may affect organizational success in manufacturing firms in 
Nigeria. Again, lack of employees' recognition programs may affect organizational success therefore, further research may also be carried out to examine the relationship between employees' recognition programs and organizational success in other sectors like the hospitality industry in Nigeria to bridge thus gap in literature.

\section{References}

1. Abbott, R. K. (1993). Performance-Based Flex: A Tool for Managing Total Compensation Costs. Compensation and Benefits Review, 18-21.

2. Amah, E. (2006). Human Resource Management. Amethyst Publishers.

3. Banker, R.D., Lee, S.Y., Potter, G. \& Srinivasan, D. (1996). Contextual analysis of Performance Impacts on Outcome-Based Incentive compensation. Academy of Management Journal, 920-948.

4. Beauchesne, . P (2002). Promising Survival and Concomitant Radiation Plus Temozolomide Followed by Adjuvant Temozolomide. Journal of clinical oncology : official journal of the American Society of Clinical Oncology. 20, 31-80. 10.1200/JCO.2002.20.14.3180.

5. DeNisi, A. S. \& Griffin, R. W. (2005). Human resource management, (2nd Ed.), Dreamtech Press.

6. Dunham, K.J. (2002). Amid Sinking Workplace Morale, Employers Turn to Recognition. Wall Street Journal, 8.

7. Flandez, R. (2009). Domino's response offers lessons in crisis management. Wall Street Journal, 26.

8. Lencioni, P. (2009). The No-Cost Way to Motivate. Business Week, 84.

9. Maher, K. \& Hudson, K. (2007). Wal-Mart to Sweeten Bonus Plans for Staff. Wall Street Journal, $3,5-9$

10. Mellahi, K., \& Wilkinson, A. (2004). Organizational Failure: A Critique of Recent Research and a Proposed Integrative Framework. Wiley-Blackwell: International Journal of Management Reviews, 3-7.

11. Miller, D., \& Friesen, P. H. (1978). Archetypes of strategy formulation', Management Science, 24, 294-316.

12. Nickels, G; McHugh, J.M \& McHugh, S. M. (2011). Understanding business. 9th Ed Irwin McGraw- Hill.

13. Reason, T. (2003). Why bonus plans fail;' CFO, 53;

14. Rheem, H. (1996). Performance Management Programs. Harvard Business. Review, 8-9.

15. Robbins , S. P. \& Coulter, M. A. (2013). Management, Global Edition. Pearson Publisher

16. Sulait, T. (2010). Relational capital and firm performance: a case of manufacturing tea firms in Uganda. Unpublished a dissertation submitted to the graduate school in partial fulfillment for the requirement of the award of a Masters degree in business administration of Makerere University.

17. Whetten, David. (1980). Organizational Decline: A Neglected Topic in Organizational Science. The Academy of Management Review. 5. 577. 10.2307/257463.

18. White, E. (2006). Employers Increasingly Favor Bonuses to 1aises. Wall Street Journal, 3. 